Zagłada Żydów. Studia i Materiały, R. 2020, nr 16

ISSN (print): 1895-247X; eISSN: 2657-3571

DOI: https://doi.org/10.32927/ZZSiM.651

\title{
Jan Borowicz
}

Uniwersytet Warszawski, Instytut Kultury Polskiej

https://orcid.org/0000-0003-2847-2686

j.borowicz@uw.edu.pl

\section{Bożena Keff, Strażnicy fatum, Warszawa: Wydawnictwo Krytyki Politycznej, 2020, 212 s.}

Książka Bożeny Keff sytuuje się w ostatnio intensywnie rozwijających się badaniach świadków Zagłady i miejsc pamięci o Zagładzie w obrębie polskiej tożsamości. Do określenia pozycji etnicznie polskich świadków Keff używa wyrażenia „strażnicy fatum”, oznaczającego sprawczych obserwatorów przemocy, pomagających Niemcom w wyłapywaniu, osaczaniu i mordowaniu Żydów (s. 13-19). Etniczni Polacy to „sygnalizacyjni gapie”, zbiorowo wskazujący na ukrywających się i uciekających Żydów, a po wojnie we własnej pamięci maskujący współudział w Zagładzie za pomocą różnych metod, z przywołaniem naczelnej kategorii „fatum” na czele. „Fatum” to powstałe w późniejszych operacjach pamięciowych przekonanie o wszechobecności i wszechwładzy niemieckich żołnierzy w okupowanej Polsce i całkowitej bezradności etnicznych Polaków, którzy nie decydują się na pomoc zbiegłym Żydom, ponieważ Niemcy i tak nieuchronnie się o nich dowiedzą. Nie o precyzję sformułowań jednak chodzi, ale o nośność wyrażenia - Keff nie interesuje ścisłe definiowanie pojęć, lecz tworzenie działających na wyobraźnię obrazów, które mają uprzytomnić szerszemu czytelnikowi mistyfikacje polskiej pamięci o Zagładzie. Kolejne pojęcie spinające w wywodzie Keff polską pamięć stanowi „zestaw z drzewkiem” (opisany już w poprzedniej książce tej autorki - Antysemityzm. Niezamknięta historia ${ }^{1}$ ), czyli szantaż etyczno-poznawczy, w którym uogólnienie postaw etnicznych Polaków wobec Żydów może nastąpić wyłącznie przez wyliczenie medali Sprawiedliwych i buchalteryjne zamknięcie dyskusji (s. 51).

To połowa książki - druga dotyczy tożsamości żydowskiej widzianej z perspektywy polskich Żydów próbujących jakoś osadzić się w miejscu wyznaczonym im przez polską kulturę. Keff wskazuje, że polscy Żydzi - zarówno przed wojną, jak i po niej - mają małe pole manewru, jeśli chodzi o aktywny udział w kształtowaniu swojej tożsamości (s. 14). Ogranicza ich bowiem swego rodzaju „regulamin gościa”, w który są wpychani przez etnicznie polskich „gospodarzy”. Życie w wykluczeniu, asymetrycznej hierarchii dominujący-zdominowani two-

${ }^{1}$ Bożena Keff, Antysemityzm. Niezamknięta historia, Warszawa: Czarna Owca, 2013, s. 191-194. 
rzy strategie przystosowawcze - autorka pisze o uniwersalizacji i maskaradzie. Badanie i opis dwóch pozycji tożsamościowych: etnicznie polskich świadków oraz polskich Żydów, wyznaczają ogólną ramę wywodu Keff.

Początkowe dwa rozdziały książki dotyczą pierwszych, tużpowojennych, literackich zapisów poświęconych bezpośredniej obserwacji Zagłady - powieści Samson (1948) Kazimierza Brandysa, opowiadań Meta (1946) Ludwika Heringa, Wielkanoc (1947) Adolfa Rudnickiego i Handel dewocjonaliami (1949) Mieczysława Frenkla - oraz analizy przekształceń i recepcji opowiadania Przy torze kolejowym (1946) Zofii Nałkowskiej. Keff wybrała teksty z pierwszych lat po wojnie ze względu na dokumentacyjną bliskość rzeczywistości wojny i Zagłady (s. 5). Nie jest jednak sproblematyzowane, na czym ta bliskość polega - w przypadku Mety można chyba myśleć nie tyle o realizmie zapisu, ile o „traumatycznym realizmie" w rozumieniu Michaela Rothberga, jeśli wziąć pod uwagę metaforyczność jego prozy². W analizowanych utworach polskie współuczestnictwo w Zagładzie zostało udokumentowane na różne sposoby: przez wskazywanie ukrywających się Żydów (zgodnie z zasadą, że „Żyd zobaczony publicznie musi umrzeć", s. 58), zerwanie empatii z ofiarami (s. 35), rozkoszowanie się śmiercią Żydów jako widowiskiem (s. 35-36, 39) oraz bezwzględne przejmowanie mienia (s. 39). Keff zwróciła uwagę, że we wszystkich tekstach zaraz potem pojawiają się operacje pamięciowe maskujące te rozpoznania przez obsesyjne wyliczanie zasług i pomocy udzielanej przez etnicznych Polaków. Naginanie prawdy historycznej w najjaskrawszej formie widać w etiudzie Przy torze kolejowym (1963) Andrzeja Brzozowskiego, w której ofiara zgadza się na swoją śmierć, wręcz prosi o nią etnicznie polskiego obserwatora. Błaganie miało zamazać przemoc, choć Keff dodaje, że film ocenzurowano, ponieważ i tak za bardzo zbliżył się do tego, czego polskim obserwatorom nie można zobaczyć (s. 78-79).

Strażnicy fatum jest książką spowinowaconą z dotyczącymi pozycji polskich świadków Zagłady projektami środowiska naukowego, z którego wywodzi się autorka ${ }^{3}$. Publikacja Keff dzieli z pracami innych badaczy tego środowiska ramę teoretyczną, w której centralną operacją polskiej pamięci jest ochrona autowi-

\footnotetext{
${ }^{2}$ Zob. Adam Lipszyc, Ludwik Hering: racja milczenia [w:] idem, Czerwone listy. Eseje frankistowskie o literaturze polskiej, Kraków: Austeria, 2018. 0 traumatycznym realizmie zob.: Michael Rothberg, Traumatic Realism: The Demands of Holocaust Representation, Minneapolis-London: University of Minnesota Press, 2000 (w tym wypadku szczególnie rozdział Unbearable Witness. Charlotte Delbo's Traumatic Timescapes).

${ }^{3}$ Elżbieta Janicka, Tomasz Żukowski, Przemoc filosemicka? Nowe polskie narracje o Żydach po roku 2000, Warszawa: Wydawnictwo IBL PAN, 2016; Zagłada w „Medalionach” Zofii Nałkowskiej. Tekst i konteksty, red. Tomasz Żukowski, Warszawa: Wydawnictwo IBL PAN, 2016; Opowieść o niewinności. Kategoria świadka Zagłady w kulturze polskiej (1942-2015), red. Maryla Hopfinger, Tomasz Żukowski, Warszawa: Wydawnictwo IBL PAN, 2018; Tomasz Żukowski, Wielki retusz: jak zapomnieliśmy, że Polacy zabijali Żydów, Warszawa: Wielka Litera, 2018; Lata czterdzieste. Początki polskiej narracji o Zagładzie, red. Maryla Hopfinger, Tomasz Żukowski, Warszawa: Wydawnictwo IBL PAN, 2019.
} 
zerunku, a podstawową relację między etnicznymi Polakami a polskimi Żydami opisuje hierarchiczna struktura kultury dominującej i podporządkowanej. „Zestaw z drzewkiem” zawarty w twierdzeniach: „1) w Polsce i tylko w Polsce w czasie okupacji karą za pomoc i ukrywanie Żydów była śmierć; 2) mimo to Polacy na wszelkie dostępne im sposoby pomagali Żydom; 3) świadczy o tym liczba polskich drzewek w Yad Vashem" (s. 51) - służy podtrzymywaniu obrazu niewinności samych siebie, a uczucie bezradności zawarte w fałszywej koncepcji „fatum” ma usprawiedliwić zerwanie więzi między świadkami a ofiarami Zagłady (s. 73). Wreszcie wszystkie te operacje mają służyć umacnianiu kultury podporządkowania: protestujący przeciwko takiej wizji przeszłości Żydzi są poddawani dyscyplinującej krytyce i/lub wykluczeniu. W zakończeniu Keff konkluduje, że jedyną tożsamością staje się „wuj Jankiel” (na podobieństwo Chaty wuja Toma Harriet Beecher-Stowe) - z uwewnętrznioną akceptacją norm polskiej kultury. Autorka przypomina, że choć w Panu Tadeuszu (1834) Jankiela jako przedstawiciela spolszczonych Żydów szanowano, to zawsze możliwa i dopuszczalna była przemoc symboliczna - gdy mówił zbyt rozwlekle, wystarczyło powiedzieć mu: „Precz stąd, Żydzie” (s. 188).

Z kolei tożsamości żydowskiej i schwytania jej w sidła polskiej kultury dotyczą rozdziały poświęcone Julianowi Tuwimowi i Tadeuszowi Różewiczowi wskazujące różne strategie przystosowawcze. W poruszającym przemówieniu Tuwima na odsłonięcie pomnika Bohaterów Getta w 1948 r. - którego jednak z niewiadomych powodów nie wygłosił - zawiera się zarazem lament ocalałego, oraz oświeceniowo-socjalistyczna wiara w uniwersalizm ludzkości, wolnej od różnic tożsamościowych. Keff pokazuje, jak w jego tekście rozpacz przekształca się we wzniosłą mobilizację, oczekiwanie rychłej konfrontacji z faszyzmem. Zawiera się to już w pierwszych zdaniach:

Nigdy nie czułem się swobodniejszy od jakiejkolwiek wspólnoty narodowej niż dziś, gdy stoję przed pomnikiem Ofiar Warszawskiego Getta, czyli nad ogromnym grobem narodu, który mnie wydał (s. 97) .

Trudno nie zrozumieć, że uniwersalizacja mogła stanowić lek na nieukojony żal otwierający się „nad ogromnym grobem narodu”. Jednocześnie Keff udowadnia, w jaki sposób oświeceniowa tradycja - w duchu Dialektyki oświecenia Adorna i Horkheimera - nie pozwalała na emancypację Żydów i w jaki sposób mówienie w Polsce o uniwersalnej kondycji ludzkiej maskowało przemoc gospodarzy wobec gości. Sięga do przykładów zachodnioeuropejskich, przywołując akcenty antysemickie w twórczości Woltera czy Szekspira, przy czym nie jest jasne, w jaki sposób ci oraz inni autorzy łączą się ze sobą. Analogiczne tezy można znaleźć w pismach przedstawicieli polskiego oświecenia, np. Stanisława Staszica, dla którego Żydzi byli głównym wykluczonym Innym, stojącym na przeszkodzie dla wyzwolenia się narodu z niedojrzałości ku uniwersalizmowi rozumu:

\footnotetext{
${ }^{4}$ Cyt. za: Piotr Matywiecki, Twarz Tuwima, Warszawa: W.A.B., 2007, s. 326.
} 
W tym nieszczęściu jeszcze byśmy przez oświecenie, przez cywilizację wznieść się i ratować mogli, lecz [...] Żydzi byli zarazą wewnątrz, zarazą ciągle politycznie ciało słabiącą i nędzniącą. Chociażby nawet to ciało nie było podzielone, chociażby po podziale znowu zjednoczonem zostało, przecież z tą wewnętrzną skazą nigdy nie można nabrać właściwych sobie sił ani czerstwości; musi na zawsze być tylko słabe, wynędzniałe i nikczemne. Żydzi po całej Polsce rozsypani, w rzędzie z swym duchem wyłączności z naszym ludem pomieszani, tylko zaplugawią cały naród, zaplugawią cały kraj, a zmieniając go w kraj żydowski, wystawią w Europie na poniewierkę i wzgardę ${ }^{5}$.

Staszic w istocie projektował nowoczesne państwo w kategoriach biopolitycznych, w których metaforyka biologiczna do opisu zdrowia polskiego ciała narodowego wyznacza Żydom miejsce choroby. Przed-nowoczesna była tutaj jedynie wiedza naukowa - Żydzi byli jeszcze zarazą, a nie zarazkami (s. 89-91). Keff ukazuje, w jaką pułapkę wikła się uniwersalistyczna koncepcja tożsamości żydowskiej, wyłaniająca się z mowy Tuwima. Szkoda, że rekonstruuje jedynie lepiej przebadany (i wygodniejszy z racji oddalenia czasowego) kontekst oświeceniowy, zostawiając na boku kwestię uniwersalizmu komunistycznego i socjalistycznego.

W inny sposób Keff ustawia twórczość Różewicza. Autorka stawia kluczowe pytanie dotyczące pozycji, z której pisze - czy jest to perspektywa żydowskiej ofiary, czy polskiego świadka Zagłady. Wskazuje na ewolucję recepcji poezji Różewicza, w której tożsamość żydowska zostaje przez badaczy i krytyków wydobyta na pierwszy plan spod maskowania i ukrywania w tomach poprzedzających Nożyk profesora (2001), będący w tym wypadku swoistym wyjściem z szafy. Keff uznaje jednak, że ta kwestia musi pozostać nierozstrzygnięta, bo jest po prostu nierozstrzygalna: czy dzieła Różewicza należy włączać w kanon polskich obserwacji Zagłady, czy wydobywać żydowską tożsamość autora, a tym samym wpisywać go w twórczość żydowskich ocalałych. Tożsamość Różewicza - i innych „maranów”, jak nazwał ich Artur Sandauer („którzy z pochodzeniem wolą się nie zdradzać [...]. A i trudno się dziwić! Za pochodzenie takie płacono drogo, a ludzie są tylko ludźmi. Ale nie mówcie mi w takim razie, że jest ono jak każde inne, gdy żyjemy w kraju, gdzie zagazowano za nie 6 milionów ludzi"6) - przyjmowałaby wtedy raczej postać wstęgi Möbiusa, w której polskość i żydowskość gładko przechodzą w siebie.

Przy tym Keff konstatuje, że Różewicz w obrębie polskiej kultury nie mógł liczyć na bezpieczną artykulację swojej tożsamości, co wyraża formuła regulaminu gościa, który ma przede wszystkim służyć kamuflowaniu wrogości i przemocy. Autorka korzysta tu z rozpoznań badaczy określających to - za tytułem książki

\footnotetext{
${ }^{5}$ Stanisław Staszic, 0 przyczynach szkodliwości żydów i o środkach usposobieniu ich, aby się społeczeństwu użytecznymi stali [w:] August Rohling, Zgubne zasady talmudyzmu do serdecznej rozwagi Żydom i chrześcijanom wszelkiego stanu, Lwów: „Gazeta Wiejska”, 1875 [1815], s. 91-92.

${ }^{6}$ Artur Sandauer, O sytuacji pisarza polskiego pochodzenia żydowskiego w XX wieku (Rzecz, którq̨ nie ja powinienem był napisać...), Warszawa: Czytelnik, 1982, s. 5.
} 
Hanny Krall - jako „sublokatorstwo” kultury polskiej ${ }^{7}$. Żydzi jako polscy goście (a nie współgospodarze) to struktura długiego trwania, kształtująca od średniowiecza pozycję w drabinie hierarchii społeczeństwa, w której Żydom bezustannie wskazuje się czasowość i ograniczoność ich pobytu na krajowym terytorium (s. 153) ${ }^{8}$. Keff uznaje to w ogólnej dygresji za trwały element polskiej pamięci.

Przyjąwszy rozważania autorki za pewnik, wydaje mi się, że należałoby się zastanowić nad niejednoznaczną kwestią, która rodzi się z zestawienia tych dwóch pozycji i tez dotyczących polskiej pamięci: w jaki sposób - w kulturze polskiej, która dzieli się na asymetryczne grupy większościowe i mniejszościowe („strażnicy fatum” oraz „zestaw z drzewkiem”) i w której Żydzi mogą być jedynie przyjezdnymi, a nie obywatelami („regulamin gościa”) - można stworzyć tożsamość żydowską pozbawioną piętna. Autorka pokazuje ten problem, stawiając ważne pytanie: „Czy stoi przed nami tylko taka alternatywa, że albo nie mówimy o tabuizowanym temacie i wtedy nie tworzymy problemu, albo mówimy, i wtedy zamykamy Żyda w getcie?" (s. 171). Następnie postuluje, aby nie traktować opisywania identyfikacji żydowskiej jako dyskryminacyjnego gestu naznaczenia, ale właściwie nie tłumaczy, w jaki sposób robić to w obrębie wspólnoty pamięciowej i tożsamościowej, w której - jak trafnie opisała Anna Zawadzka - można obrażać „nie Żyda, lecz Żydem”. Keff daje przykłady wielu „nieudanych” żydowskich tożsamości - młodzieży podążającej za modą (s. 147, 201) czy zasymilowanych „normalsów”, przepraszających za żydokomunę i żydowski antypolonizm, czym legitymizują dyskryminacyjny porządek społeczny (s. 189-200). Opis panoptycznych struktur polskiej kultury dobrze pokazuje przemoc wpisaną w tzw. relacje polsko-żydowskie, ale nie jestem pewien, czy pozwala stworzyć miejsce na emancypacyjną i pozytywną tożsamość żydowską, miejsce do życia, które nie stanowiłoby ani skansenu dla egzotycznych cudzoziemców, ani sutereny dla wynajmujących pokój.

\section{BIBLIOGRAFIA}

Keff Bożena, Antysemityzm. Niezamknięta historia, Warszawa: Czarna Owca, 2013.

Matyjaszek Konrad, Produkcja przestrzeni żydowskiej w dawnej i współczesnej Polsce, Kraków: Universitas, 2019.

Sandauer Artur, O sytuacji pisarza polskiego pochodzenia żydowskiego w XX wieku (Rzecz, która nie ja powinienem był napisać...), Warszawa: Czytelnik, 1982.

Zawadzka Anna, Polska walczq̨ca [w:] Wojciech Wilczyk, Święta wojna (2009-2014), Łodź: Atlas Sztuki, Kraków: Karakter, 2014.

${ }^{7}$ Elżbieta Janicka, Joanna Tokarska-Bakir, Sublokatorstwo jako kategoria kultury polskiej, „Studia Litteraria et Historica” 2013, nr 2; eaedem, „Sublokatorka” po latach. Z Hannq Krall rozmawiają Elżbieta Janicka i Joanna Tokarska-Bakir. Warszawa, 28 lutego i 8 marca 2013 roku, ibidem; Konrad Matyjaszek, Produkcja przestrzeni żydowskiej w dawnej i współczesnej Polsce, Kraków: Universitas, 2019.

${ }^{8}$ Zob. Matyjaszek, Produkcja przestrzeni żydowskiej..., s. 57.

${ }^{9}$ Anna Zawadzka, Polska walcząca [w:] Wojciech Wilczyk, Święta wojna (2009-2014), Łodź: Atlas Sztuki, Kraków: Karakter, 2014, s. 10-16. 